MAJA WOJCIECHOWSKA

Instytut Filologii Polskiej

Uniwersytet Gdański

e-mail: maja.wojciechowska@gmail.com

\title{
INDYWIDUALNY KAPITAŁ SPOŁECZNY I AKTYWNOŚĆ SPOŁECZNA KADRY KIEROWNICZEJ BIBLIOTEK. PRZEGLĄD WYNIKÓW BADAŃ Z DWUDZIESTU KRAJÓW ŚWIATA
}

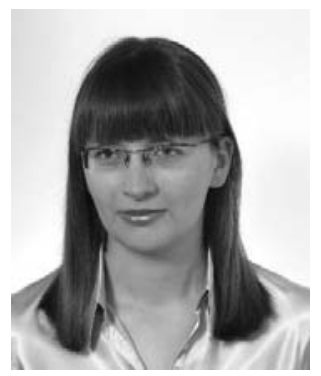

Maja Wojciechowska, dr hab., profesor w Instytucie Filologii Polskiej Uniwersytetu Gdańskiego; zainteresowania naukowe: zarządzanie bibliotekami, marketing instytucji kultury, niematerialne zasoby organizacyjne, zarządzanie zasobami ludzkimi, kapitał społeczny. Redaktor naczelna czasopisma "Zarządzanie Biblioteką", organizator Bałtyckiej Konferencji Zarządzanie i Organizacja Bibliotek, członek sekcji IFLA Management and Marketing, przewodnicząca Komisji Zarządzania i Marketingu SBP, w latach 2006-2013 dyrektor biblioteki Ateneum - Szkoły Wyższej w Gdańsku. Autorka i redaktor licznych prac, w tym m.in. Intangible organizational resources: Analysis of resource-based theory and the measurement of library effectiveness (Springer 2016), Leksykon zarzadzania i marketingu w bibliotekoznawstwie (SBP, 2019), Zarzadzanie biblioteka (SBP, 2019), Kształtowanie kapitału społecznego: ujęcie z perspektywy bibliotekoznawczej (Difin, 2019), Social capital, trust and social activity among librarians: Results of research conducted in 20 countries across the world ("Library and Information Science Research", 2020).

SŁOWA KLUCZOWE: Aktywność społeczna. Kadra kierownicza bibliotek. Kapitał społeczny. Sieci społeczne.

ABSTRAKT: Teza/cel artykułu - W artykule przedstawiono wyniki badań dotyczących poziomu indywidualnego kapitału społecznego bibliotekarzy z dwudziestu krajów świa- 
ta oraz ich aktywności społecznej, mających wpływ na integrację z lokalną społecznością oraz możliwość rozwijania usług bibliotecznych. Celem badań było ustalenie, czy kadra kierownicza bibliotek, w porównaniu z pracownikami liniowymi, dysponuje bogatszą siecią społeczna, jest aktywniejsza społecznie i chętniej podejmuje współpracę, a zatem: czy posiada cechy uznawane za istotne na stanowiskach kierowniczych. Metody badań - Na pytania zawarte w ankiecie elektronicznej uzyskano ogółem 6593 ważnych odpowiedzi, które następnie poddano analizie statystycznej. Obliczono statystyki analizy wariancji ANOVA jednoczynnikowa, zastosowano test chi-kwadrat niezależności oraz test różnic U Manna-Whitneya. Wyniki - Badania potwierdziły większą aktywność społeczną kadry kierowniczej bibliotek oraz wyższy poziom indywidualnego kapitału społecznego obliczany w oparciu o generator zasobów - Kwestionariusz do Pomiaru Indywidualnego Kapitału Społecznego.

\section{KAPITAŁ SPOŁECZNY}

Kapitał społeczny to stosunkowo nowa koncepcja, powstała w pierwszej połowie XX w., wykorzystywana głównie w naukach społecznych, ale również $\mathrm{w}$ : antropologii, ekonomii, geografii, kulturoznawstwie, politologii, a także naukach o zarządzaniu i bibliologii. Bazuje na założeniu, że sieci społeczne, normy i zaufanie umożliwiają członkom społeczeństwa bardziej skuteczne działania oraz osiąganie celów indywidualnych i grupowych. Szeroko rozumiana współpraca i integracja uznawane są tu za źródło powodzenia określonych środowisk oraz jedną z przyczyn ich rozwoju.

Choć kapitał społeczny rozumiany jako „możliwość uzyskiwania korzyści na mocy członkostwa w sieciach społecznych lub innych strukturach społecznych" (Portes, 1998) początkowo budził zainteresowanie głównie socjologów - warto wymienić tu choćby nazwiska Jamesa Colemana, Pierre-Félixa Bourdieu, Nana Lina, Roberta Putnama i Alejandro Portesa - to obecnie jego znaczenie badane jest w różnych sferach i wymiarach aktywności ludzkiej. W bibliotekarstwie kapitał społeczny można określić jako „zdolność jednostek do łączenia się w grupy i tworzenia sieci relacji, opartych na zaufaniu, wzajemnym wsparciu i integracji, umożliwiającą realizację wspólnych interesów, zadań, projektów, przedsięwzięć. W ramach badań bibliologicznych kapitał społeczny rozpatrywany jest zarówno na poziomie grup społecznych (otoczenie biblioteki), jak również na poziomie organizacyjnym (biblioteka jako organizacja). Badane są możliwości, jakie posiadają biblioteki do wspierania rozwoju kapitału społecznego swoich pracowników oraz społeczności lokalnych, jak również korzyści, jakie może przynieść rozwój kapitału społecznego" (Wojciechowska et al., 2019, s. 94). Z kolei w naukach o zarządzaniu kapitał społeczny może być analizowany pod kątem oceny wpływu więzi międzyludzkich i ich rezultatów na dobrostan pracowników, klientów, skuteczność organizacyjną kadry kierowniczej i wyniki działalności organizacji. 
Kapitał społeczny, pomimo iż ma charakter dobra wspólnego, zaś jego główną cechą jest kolektywizm, posiada również swój wymiar indywidualny. W tym znaczeniu jest to zbiór zasobów należących do członków społecznej siatki jednostki, które mogą stać się dla niej dostępne jako rezultat charakteru wcześniejszych kontaktów (Van der Gaag i Snijders, 2004, p. 201). Zasoby te mogą być wykorzystywane zarówno do realizacji celów indywidualnych (własnych potrzeb jednostki), celów organizacyjnych biblioteki, jak również udostępniane w ramach wsparcia użytkowników/ społeczności lokalnej.

Z punktu widzenia skuteczności organizacyjnej biblioteki szczególnie istotne znaczenie ma indywidualny kapitał społeczny (IKS) oraz aktywność społeczna dyrektora oraz kadry kierowniczej. Aktywność ta oraz dostęp do określonych sieci i zasobów mogą mieć kluczowe znaczenie dla rozwoju instytucji oraz intensywności jej działań na rzecz użytkowników. W celu zbadania postaw kadry kierowniczej bibliotek oraz określenia poziomu jej indywidualnego kapitału społecznego przeprowadzono badania ankietowe, które zostaną opisane w dalszej części artykułu.

\section{CEL ORAZ METODYKA PRZEPROWADZONYCH BADAŃ}

Celem wykonanej analizy było ustalenie, czy kadra kierownicza bibliotek charakteryzuje się wyższym poziomem kapitału społecznego oraz większą aktywnością społeczna, w porównaniu z pracownikami bibliotek zatrudnionymi na stanowiskach szeregowych. Jak pokazują liczne badania, przynależność zawodowa oraz poziom w hierarchii organizacyjnej instytucji (stanowiska liniowe, kierownicze i dyrektorskie) wiążą się zwykle z pewnymi modelami zachowań. Pracownicy umysłowi, wysoko kwalifikowani, na stanowiskach kierowniczych prowadzą zazwyczaj aktywne życie towarzyskie, budując ze znajomymi i przyjaciółmi bogatą sieć relacji uważaną za desygnat kapitału społecznego (Growiec, 2011, s. 6569). Funkcjonowanie w aktywnych sieciach społecznych (mierzone m.in. liczbą znajomych i przyjaciół) oraz wysoki poziom indywidualnego kapitału społecznego umożliwia z kolei rozwój osobisty i zawodowy oraz daje szansę wsparcia lokalnej społeczności i sieci zawodowej, w której funkcjonuje jednostka.

W ramach przeprowadzonej analizy wyodrębniono trzy główne obszary badań, tj.:

- diagnozę poziomu zasobów indywidualnego kapitału społecznego kadry kierowniczej bibliotek;

- obszar związany z zaufaniem i aktywnością społeczną kadry kierowniczej;

- obszar dotyczący aktywności obywatelskiej kadry kierowniczej. 
Zwrócono uwagę na następujące kwestie:

- Czy kadra kierownicza bibliotek (tj. dyrektorzy i kierownicy) posiada wyższy poziom indywidualnego kapitału społecznego?

- Czy kadra kierownicza bibliotek posiada większą liczbę znajomych niż pozostała kadra bibliotek, a więc czy utrzymuje szerszą sieć kontaktów?

- Czy kadra kierownicza bibliotek bardziej angażuje się w działania społeczne?

- Kto deklaruje większy wpływ na społeczność lokalną związaną z biblioteką - kadra kierownicza czy pracownicy liniowi?

- Jaki jest poziom zaufania wśród kadry kierowniczej bibliotek do innych ludzi?

- Czy kadra kierownicza uważa za pożądaną aktywną postawę i zaangażowanie kadry niższego szczebla?

- Czy kadra kierownicza bibliotek angażuje się w większym stopniu niż pracownicy liniowi w aktywność obywatelska, która jest jednym z wyznaczników kapitału społecznego?

- Jakimi wartościami kieruje się w życiu kadra kierownicza bibliotek, jakie wartości są dla niej kluczowe?

Wymienione kwestie - w niektórych badaniach uznawane za wskaźniki kapitału społecznego - mają istotne znaczenie dla przebiegu współpracy pomiędzy bibliotekami a obsługiwanymi przez nie społecznościami. Niski poziom któregoś ze wskaźników może sygnalizować problemy $\mathrm{w}$ relacjach $\mathrm{z}$ otoczeniem oraz konieczność zmiany zachowań. Pozwalają również na dokonanie częściowej oceny postaw kadry kierowniczej, która powinna charakteryzować się większą aktywnością i otwartością niż pozostali pracownicy.

Przedstawione pytania zostały skierowane drogą ankiety elektronicznej do bibliotekarzy zatrudnionych w bibliotekach różnych typów z 20 krajów świata: Australii, Austrii, Belgii, Białorusi, Czech, Danii, Francji, Irlandii, Kanady, Niemiec, Nowej Zelandii, Polski, Rosji, Słowacji, Stanów Zjednoczonych, Szwajcarii, Szwecji, Ukrainy, Węgier oraz Wielkiej Brytanii. Uzyskano ogółem 6593 ważne odpowiedzi udzielone przez respondentów w 2018 i 2019 r. Prezentowana analiza stanowi część badania dotyczącego indywidualnego kapitału społecznego bibliotekarzy, rozpoczętego w drugiej połowie 2018 r. i w dalszym ciągu kontynuowanego, którego zakończenie planowane jest na $2022 \mathrm{r}$.

W celu opracowania uzyskanych danych obliczono wartości statystyki jednoczynnikowej analizy wariancji ANOVA ${ }^{1}$; do weryfikacji istotności zależ-

${ }^{1}$ ANOVA (ANalysis Of VAriance) - narzędzie pozwalające porównywać więcej niż dwie badane grupy wydzielone przez kategorie jednej zmiennej (analiza jednoczynnikowa) lub wielu zmiennych (analiza wieloczynnikowa). 
ności między odpowiedziami na skali nominalnej i zajmowanego stanowiska zastosowano test chi-kwadrat niezależności, zaś do oceny różnic w częstości podejmowanych czynności między dwiema grupami pracowników zastosowano test różnic U Manna-Whitneya. Wszystkie testy zostały obliczone na poziomie istotności statystycznej alfa=0,05. Poziom indywidualnego kapitału społecznego uzyskano w oparciu o tzw. generator zasobów - Kwestionariusz do Pomiaru Indywidualnego Kapitału Społecznego (KPIKS) opracowany przez polskiego psychologa Rafała Styłę (Styła, 2009) na podstawie narzędzia wstępnie przygotowanego przez Martina van der Gaaga i Toma Snijdersa - holenderskich badaczy indywidualnego kapitału społecznego (Van der Gaag, Snijders, 2004 i 2005) - zob. tab. 1.

Tabela 1

Normy KPIKS

\begin{tabular}{|c|c|c|}
\hline Stanina & $\begin{array}{l}\text { Wynik surowy } \\
\text { KPIKS-20 }\end{array}$ & Interpretacja wyniku \\
\hline 1 & Do 52 & \multirow{3}{*}{$\begin{array}{l}\text { Niski poziom indywidualnego kapitału społecznego } \\
\text { oznaczający, że osoba we własnej siatce społecznej ma } \\
\text { niski potencjał uzyskania dostępu do różnych atrak- } \\
\text { cyjnych zasobów. Musi ona przede wszystkim uzyski- } \\
\text { wać dostęp do tego typu zasobów przez mechanizmy } \\
\text { rynkowe, np. w przypadku tłumaczenia tekstu z ję- } \\
\text { zyka francuskiego na polski jest wyższe prawdopodo- } \\
\text { bieństwo, że zmuszona będzie do wynajęcia tłumacza. }\end{array}$} \\
\hline 2 & $53-56$ & \\
\hline 3 & $57-62$ & \\
\hline 4 & $63-68$ & \multirow{3}{*}{$\begin{array}{l}\text { Przeciętny poziom indywidualnego kapitału społecz- } \\
\text { nego oznaczający przeciętny potencjał uzyskania we } \\
\text { własnej siatce społecznej dostępu do różnych atrak- } \\
\text { cyjnych zasobów. Osoba ta w niektórych przypadkach } \\
\text { może liczyć na to, że uzyska dostęp do różnych za- } \\
\text { sobów dzięki posiadanemu kapitałowi społecznemu, } \\
\text { w innych natomiast zmuszona będzie do uzyskania } \\
\text { tych zasobów przez zakupienie ich na ogólnie dostęp- } \\
\text { nym rynku. }\end{array}$} \\
\hline 5 & $69-72$ & \\
\hline 6 & $73-75$ & \\
\hline 7 & $76-78$ & \multirow{3}{*}{$\begin{array}{l}\text { Wysoki poziom indywidualnego kapitału społecznego } \\
\text { oznaczajacy wysoki potencjał uzyskania we własnej } \\
\text { siatce społecznej dostępu do różnych atrakcyjnych } \\
\text { zasobów. Osoba ta, gdy zajdzie taka potrzeba, jest } \\
\text { w stanie dzięki swojej siatce społecznej uzyskać do- } \\
\text { stęp nawet do rzadkich zasobów, np. w przypadku na- } \\
\text { głego problemu z prawem z dużym prawdopodobień- } \\
\text { stwem będzie miała możliwość zgłoszenia się o pomoc } \\
\text { do jakiegoś zaprzyjaźnionego prawnika na zasadach } \\
\text { korzystniejszych niż rynkowe. }\end{array}$} \\
\hline 8 & $79-80$ & \\
\hline 9 & $\mathrm{X}$ & \\
\hline
\end{tabular}

Źródło: oprac. na podstawie Rafał Styła. Kwestionariusz do Pomiaru Indywidualnego Kapitału Społecznego (KPIKS) - wstępna propozycja oparta na idei generatora zasobów Toma Snijdersa. Psychologia Społeczna. 2009, nr 1/2, s. 72. 


\section{WYNIKI BADANIA}

W celu oceny różnic w poziomie indywidualnego kapitału społecznego różnych grup pracowników bibliotek obliczono statystyki analizy wariancji ANOVA jednoczynnikowa. Jak wynika z badania typ stanowiska istotnie różnicuje $(\mathrm{F}(2 ; 6590)=5,579 ; \mathrm{p}=0,004)$ poziom indywidualnego kapitału społecznego (szerz. zob. Tab. 2 i Rys. 1). Średni poziom indywidualnego kapitału społecznego dla wszystkich pracowników bibliotek (niezależnie od pełnionego stanowiska) wynosi 66,74, a więc mieści się w czwartej staninie norm KPIKS i stanowi przeciętny poziom indywidualnego kapitału społecznego. Pracownicy bibliotek na stanowiskach niekierowniczych mają niższy poziom indywidualnego kapitału społecznego (średnia $=66,34$ ) od dyrektorów (średnia=67,42) i kierowników (średnia=67,15), co jest zbieżne $\mathrm{z}$ wynikami innych badań (prowadzonych w różnych typach organizacji), według których to osoby na średnich i wyższych stanowiskach kierowniczych posiadają najwyższy poziom indywidualnego kapitału społecznego. Dzięki temu są w stanie skuteczniej działać, wykorzystując sieć kontaktów i udostępnione zasoby, w celu osiągania pożądanych celów. Wysoki poziom indywidualnego kapitału społecznego zwiększa skuteczność dyrektora oraz kadry kierowniczej.

Tabela 2

Statystyki opisowe poziomu indywidualnego kapitału społecznego według stanowiska $\mathrm{z}$ testem ANOVA jednoczynnikowa

\begin{tabular}{|l|c|c|c|c|c|}
\hline Stanowisko & $\mathrm{N}$ & Średnia & $\begin{array}{c}\text { Odchylenie } \\
\text { standardowe }\end{array}$ & Minimum & Maksimum \\
\hline Dyrektor & 1173 & 67,42 & 11,01 & 20,00 & 80,00 \\
\hline Kierownik & 1673 & 67,15 & 11,58 & 20,00 & 80,00 \\
\hline Pracownik liniowy & 3747 & 66,34 & 10,56 & 30,00 & 80,00 \\
\hline Ogółem & 6593 & 66,74 & 11,21 & 20,00 & 80,00 \\
\hline
\end{tabular}

$\mathrm{F}(2 ; 6590)=5,579 ; \mathrm{p}=0,004$

Źródło: oprac. własne.

W tabeli 3 zamieszczono statystyki testu chi-kwadrat. Jak wynika $\mathrm{z}$ uzyskanych danych istotne statystycznie $(\mathrm{p}<0,01)$ jest, że kadrze kierowniczej częściej $(84,2 \%)$ niż pracownikom liniowym $(77,9 \%)$ zdarzało się dobrowolnie i nieodpłatnie pracować na rzecz swojego środowiska, kościoła, osiedla, wsi, miasta albo też pracować społecznie na rzecz potrzebujących. Podobnie $(p<0,01)$ kadrze kierowniczej częściej $(47,0 \%)$ niż pracownikom liniowym $(42,7 \%)$ w przeciągu ostatnich pięciu lat zdarzyło się pracować jako wolontariusz. Jest to dobry wynik, ponieważ wskazuje na aktywność społeczną kadry kierowniczej, która przy opisanej postawie nie będzie blokowała aktywności społecznej niższego personelu, może również takie działania wspierać oraz chętniej podejmować akcje instytu- 


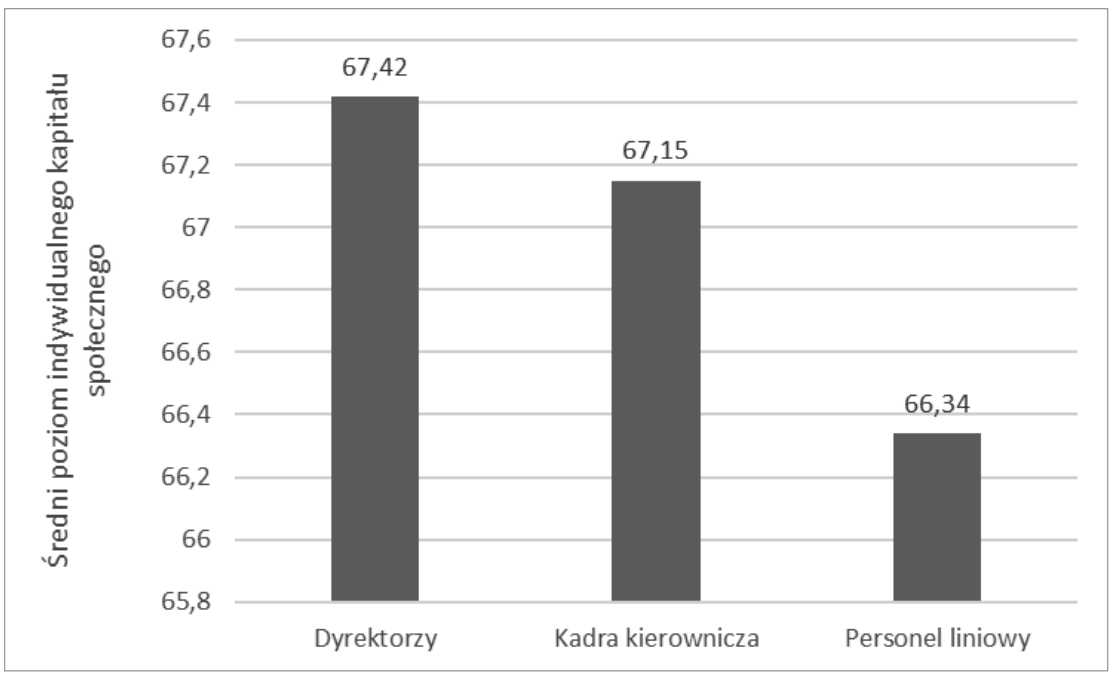

Rys. 1. Wykres wartości średnich poziomu indywidualnego kapitału społecznego według stanowiska

Źródło: oprac. własne.

cjonalne skierowane na wsparcie lokalnych społeczności. Warto zwrócić także uwagę, że dyrektorzy częściej reprezentują przekonanie, iż mogą mieć wpływ na otoczenie zewnętrzne, co łączy się zwykle z inicjatywnością i większą chęcią zaangażowania w sprawy innych. Jak pokazują dane - istotne statystycznie $(p<0,01)$ jest również, że dyrektorzy częściej $(28,4 \%)$ niż pracownicy liniowi (18,5\%) uważaja że duży wpływ na życie lokalnej społeczności mają osoby takie jak oni.

Ważną kwestią, kluczową dla rozwoju kapitału społecznego oraz mającą wpływ na stosunki ze współpracownikami oraz otoczeniem zewnętrznym jest zaufanie do drugiego człowieka. Jak pokazują badania, poziom zaufania w Polsce jest niewielki i plasuje się na jednym z najniższych miejsc w Europie (Raport o Kapitale Intelektualnym Polski, 2008). Pracownicy polskich bibliotek wypadają w badaniach lepiej, gdyż poziom ich indywidualnego kapitału społecznego wynosi 67,62 , co oznacza przeciętny a nie niski poziom IKS (Wojciechowska, 2019, s. 365). W przypadku wyodrębnienia stanowiska wśród respondentów uczestniczących w omawianym badaniu dyrektorzy częściej (58,2\%) niż pracownicy liniowi $(49,9 \%)$ zgadzają się ze stwierdzeniem „Większości ludzi można ufać” $(p<0,01)$. Również istotny statystycznie $(\mathrm{p}=0,003)$ jest wniosek, że dyrektorzy nieznacznie częściej (97,3\%) niż pracownicy liniowi (93,7\%) uważają że biblioteka jest instytucja której można ufać. Dyrektorzy częściej $(72,8 \%)$ niż pracownicy liniowi $(64,4 \%)$ zgadzają się ze stwierdzeniem "Mogę ufać większości współpracowników" ( $p=0,039)$. Podobnie dyrektorzy częściej 
(68,8\%) niż pracownicy liniowi $(63,7 \%)$ zgadzają się ze stwierdzeniem „Mogę ufać mojemu szefowi” $(\mathrm{p}<0,01)$. Wyższy poziom zaufania wśród kadry kierowniczej ułatwia budowanie relacji z personelem oraz umożliwia delegowanie uprawnień. Stanowi również podstawę do nawiązywania kontaktów z partnerami zewnętrznymi oraz tworzenia atmosfery współpracy z lokalną społecznością. Może stać się zatem „motorem” wielu pozytywnych działań.

W tym kontekście należy wspomnieć, że istotne statystycznie $(\mathrm{p}<0,01)$ jest, że dyrektorzy częściej (92,0\%) niż pracownicy liniowi (86,2\%) zgadzają się $\mathrm{w}$ większym stopniu, aby biblioteka się rozwijała, potrzebne są wspólne działania organów prowadzących: dyrekcji oraz pracowników. Podejście to powinno jednak być poparte konkretnymi działaniami, np. $\mathrm{w}$ postaci aktywizowania personelu biblioteki, przekazywania mu części uprawnień decyzyjnych, a przede wszystkim nieblokowania oddolnych inicjatyw i zaangażowania. Dyrektorzy częściej (31,5\%) niż pracownicy liniowi $(28,6 \%)$ uważają że za wygląd biblioteki i jej bezpośredniego otoczenia odpowiadają dyrekcja i pracownicy $(p<0,01)$. Natomiast pracownicy liniowi częściej dodatkowo uwzględniają użytkowników. Można przypuszczać, że personel liniowy w większym stopniu docenia rolę użytkowników ponieważ ma z nimi regularny kontakt i może bezpośrednio obserwować zaangażowane postawy wybranych przedstawicieli lokalnych społeczności. To pozytywne nastawienie bibliotekarzy do czytelników powinno zostać wykorzystane przez kadrę zarządzającą do budowania społeczności skupionej wokół biblioteki. Nie jest to zadanie łatwe, jednak jak pokazuje doświadczenie innych instytucji publicznych tylko zaangażowanie odbiorców usług może prowadzić do pełnej integracji i dbałości o współdzielone dobra i wartości. Postuluje się, by lokalne społeczności przekształcać z klientów we współgospodarzy instytucji społeczno-kulturalnych.

W ramach badania analizowano również chęć pomocy, która wymagałaby dokonania rezygnacji z części wynagrodzenia. W tej hipotetycznej sytuacji istotnie statystycznie $(p<0,01)$ dyrektorzy częściej $(23,4 \%)$ niż pracownicy liniowi $(16,2 \%)$ zgadzali się na obniżenie swojego wynagrodzenia, aby ratować bibliotekę przed upadkiem. Natomiast pracownicy liniowi częściej wskazywali, że udzieliliby pomocy, by stworzyć szansę zatrudnienia osobie głęboko potrzebującej. Wśród kadry kierowniczej widać zatem nastawienie na ochronę instytucji, zaś w przypadku pracowników liniowych na pomoc drugiemu człowiekowi. Interpretując powyższe odpowiedzi, należy jednak mieć na uwadze, iż są to jedynie deklaracje pomocy, które w przypadku zaistnienia opisywanej sytuacji mogłyby zostać wycofane (respondenci $\mathrm{w}$ badaniach ankietowych często chcą prezentować się jako osoby szlachetne i prawe), pokazują jednak pewne różnice $\mathrm{w}$ podejściu do pomagania innym. 
Ciekawe wyniki uzyskano w pytaniu: Czy dyrekcja Pana/Pani biblioteki wspiera działania prospołeczne? Dyrektorzy częściej (40,08\%) niż pracownicy liniowi $(30,7 \%)$ deklarowali: „tak, uważa je za element misji biblioteki" $(p<0,01)$. Natomiast pracownicy liniowi częściej $(15,7 \%)$ niż dyrektorzy (8,1\%) wskazywali odpowiedź: „nie, stara się unikać tego typu akcji, pochłaniają tylko pieniądze i czas pracowników". Można przypuszczać, że tak znaczące różnice w odpowiedziach wynikają ze złej komunikacji pionowej-tj. dyrekcja nie daje jasnego przekazu personelowi, że jest otwarta na działania prospołeczne lub też tylko deklaruje taką postawę, a $\mathrm{w}$ rzeczywistości nie ułatwia wspomnianej aktywności. W obu przypadkach pożądane byłoby jasne określenie, które typy działań i na jakich zasadach mogą być prowadzone przez bibliotekę. Istotnie statystycznie $(\mathrm{p}=0,039)$ dyrektorzy częściej również $(71,1 \%)$ niż pracownicy liniowi (62,3\%) deklarują, że znają jakiegoś bibliotekarza, o którym wiadomo, że dobrowolnie i nieodpłatnie pracuje na rzecz swojego środowiska, kościoła, osiedla, wsi lub miasta albo też pracuje społecznie na rzecz potrzebujących.

W kwestionariuszu zawarto także pytania dotyczące aspiracji życiowych bibliotekarzy oraz ważnych dla nich celów, stanowiących miarę sukcesu życiowego. Wyróżniona została sfera rodzinna, zawodowa, społeczna, finansowa, a nawet poczucie wolności, które dla niektórych ludzi może stanowić istotny czynnik satysfakcji. Dla kadry kierowniczej częściej ważne, niż dla pracowników liniowych, było to, aby móc robić w życiu tylko to, na co się ma ochotę oraz odnieść sukces zawodowy. Takie nastawienie na karierę zawodową oraz chęć niezależności wśród dyrektorów i kadry średniego szczebla nie budzi jednak zdziwienia i wydaje się naturalne, a nawet pożądane.

Kolejna, istotną w badaniach kapitału społecznego, sferą jest tzw. aktywność obywatelska. W tabeli 4 i na rysunku 2 zamieszczono porównanie pracowników liniowych z kadrą kierowniczą w zakresie częstości podejmowanych czynności związanych z szeroko rozumianą aktywnością obywatelską, uznawaną za element kapitału społecznego. W tym celu zastosowano test U Manna-Whitneya. Przedstawione respondentom pytania $\mathrm{z}$ tego zakresu miały dwojakie znaczenie $-\mathrm{z}$ jednej strony istotne jest, by bibliotekarze byli aktywnymi członkami swojej społeczności, z drugiej zaś - biblioteki coraz częściej uczestniczą w różnego rodzaju programach lub same prowadzą rozmaite kursy, spotkania i prezentacje z zakresu edukacji obywatelskiej. Dlatego też bibliotekarze-edukatorzy sami powinni posiadać doświadczenie praktyczne i kompetencje w zakresie prowadzenia aktywnego życia obywatelskiego oraz winni dalej przekazywać pożądane wzorce zachowań. Wydaje się, że w tym przypadku kadra menedżerska powinna odznaczać się większą aktywnościa, jednak badania nie potwierdziły w pełni tego zjawiska. 
善

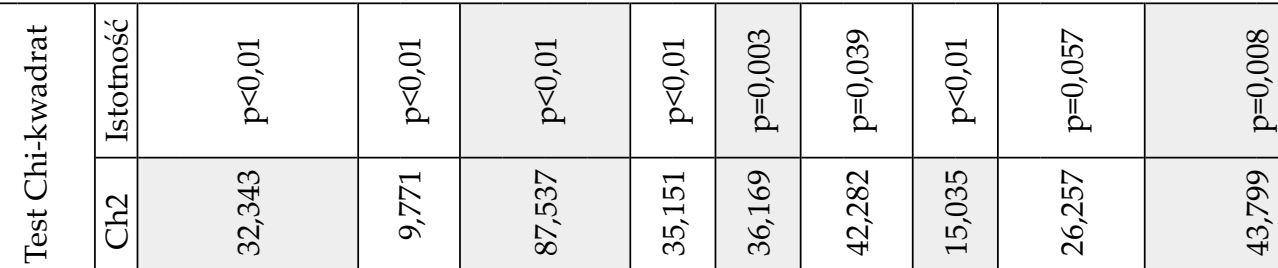

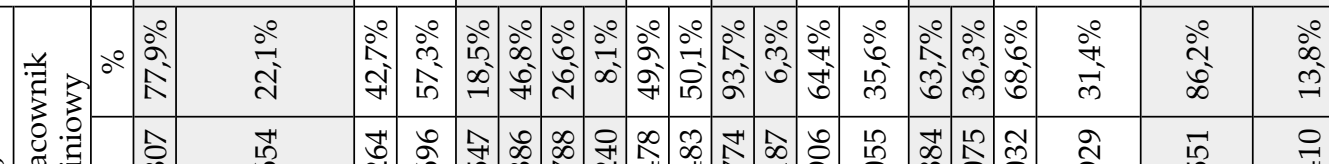

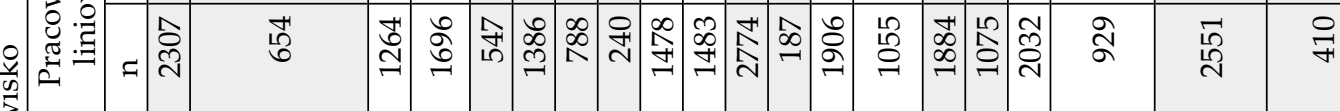
के

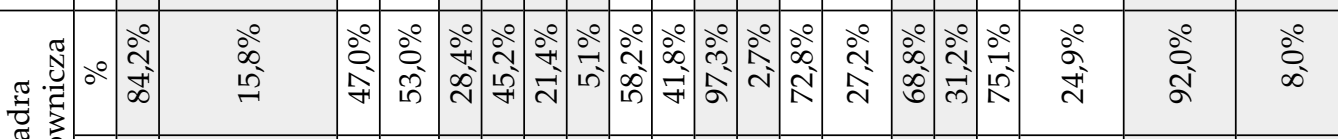

.

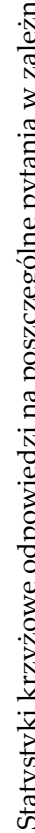

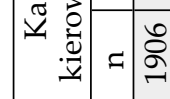

怘

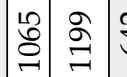

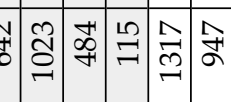

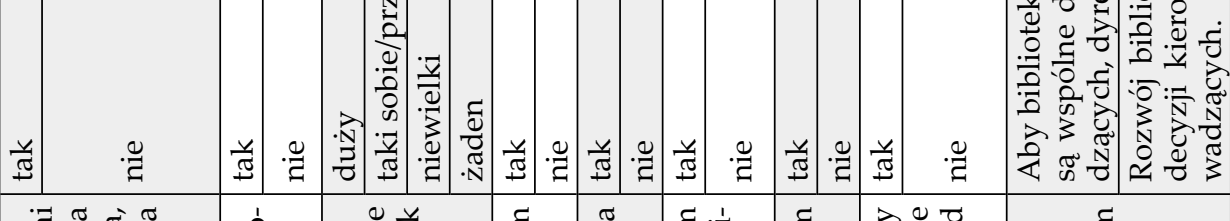

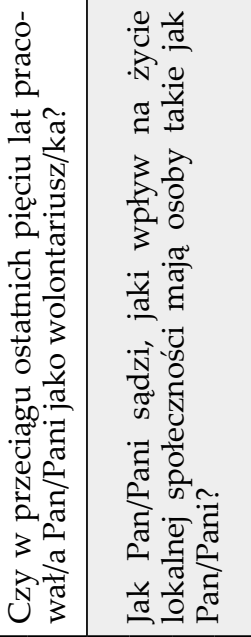

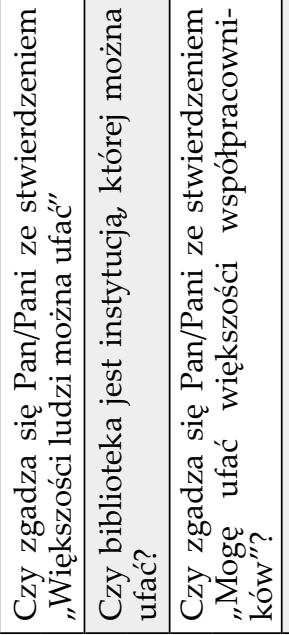




\begin{tabular}{|c|c|c|c|c|c|c|c|c|c|c|c|c|c|c|c|c|c|c|c|}
\hline & & 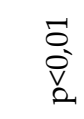 & & & & 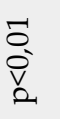 & & $\begin{array}{l}\tilde{\sigma} \\
\stackrel{0}{v} \\
\text { a }\end{array}$ & & & 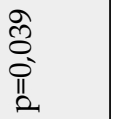 & 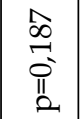 & $\begin{array}{l}\text { m } \\
8 \\
0 \\
0 \\
0\end{array}$ & 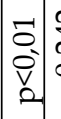 & 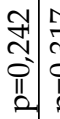 & 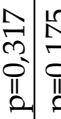 & 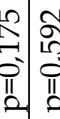 & 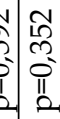 & \\
\hline & & 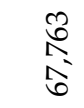 & & & & \begin{tabular}{l}
8 \\
0 \\
0 \\
0 \\
\hdashline
\end{tabular} & & $\begin{array}{l}\text { 乃ె } \\
\text { के } \\
\text { के }\end{array}$ & & & \begin{tabular}{l}
$\infty$ \\
$\infty$ \\
$m$ \\
\multirow{f}{*}{}
\end{tabular} & $\underset{F}{\stackrel{F}{F}}$ & $\begin{array}{l}\hat{\mathrm{N}} \\
\hat{2} \\
\infty\end{array}$ & 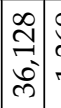 & 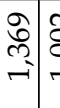 & 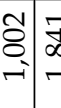 & 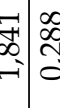 & $\begin{array}{lll}0 & 0 \\
0 & 0 \\
& 0 \\
& 0\end{array}$ & \\
\hline 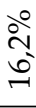 & 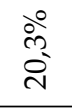 & 仓े & 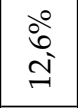 & $\begin{array}{l}\stackrel{\circ}{\hat{N}} \\
\stackrel{2}{\circ}\end{array}$ & 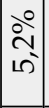 & \begin{tabular}{l|l}
0 & 0 \\
0 & 0 \\
0 \\
0
\end{tabular} & \begin{tabular}{c|c}
0 & 0 \\
1 & 0 \\
0 & 0 \\
0 & 0 \\
0
\end{tabular} & $\begin{array}{l}00 \\
\text { oे } \\
\text { ते }\end{array}$ & $\begin{array}{l}\stackrel{0}{\Lambda} \\
\stackrel{1}{\circ} \\
\stackrel{-}{1}\end{array}$ & 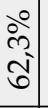 & $\begin{array}{l}\stackrel{\circ}{人} \\
\stackrel{\text { }}{0}\end{array}$ & $\stackrel{\circ}{\stackrel{\circ}{\sim}}$ & $\begin{array}{l}0 \\
0 \\
6 \\
10 \\
n\end{array}$ & $\mid \begin{array}{l}0 \\
\stackrel{0}{1} \\
\sigma^{2}\end{array}$ & 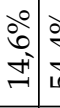 & 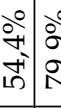 & 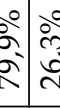 & 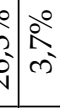 & \\
\hline$\stackrel{\infty}{\infty}$ & 8 & ๙ू & ని & م્ & ڤొ) & ક્ & ঠீ ঞ̊ & $\begin{array}{l}\infty \\
\infty \\
10 \\
\end{array}$ & $\stackrel{18}{\not}$ & $\begin{array}{l}\stackrel{1}{+} \\
\stackrel{0}{\sigma}\end{array}$ & 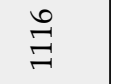 & ชู & 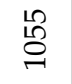 & $\begin{array}{l}\infty \\
\infty \\
10\end{array}$ & $\vec{F}$ & 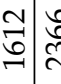 & \begin{tabular}{l|l} 
& $\infty$ \\
ते & $\stackrel{\infty}{\wedge}$
\end{tabular} & F & \\
\hline $\begin{array}{l}\circ \\
\stackrel{\circ}{+} \\
\text { సे }\end{array}$ & $\begin{array}{l}\stackrel{0}{ } \\
\text { ले } \\
\text { ते }\end{array}$ & $\begin{array}{l}\stackrel{0}{\circ} \\
\text { in } \\
\text { ¿े }\end{array}$ & 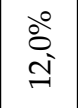 & $\begin{array}{l}\stackrel{0}{\circ} \\
\stackrel{+}{+}\end{array}$ & \begin{tabular}{|l|}
$\stackrel{0}{0}$ \\
$n^{2}$
\end{tabular} & 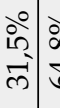 & 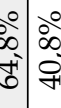 & $\frac{\circ}{\stackrel{\circ}{二}}$ & $\frac{\circ}{\circ}$ & $\begin{array}{l}0 \\
\circ \\
= \\
\end{array}$ & $\begin{array}{l}\text { 今े } \\
\text { के } \\
\text { సे }\end{array}$ & 犬̊ & $\begin{array}{l}\stackrel{0}{0} \\
\infty \\
\dot{\infty}\end{array}$ & 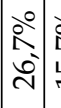 & 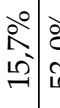 & 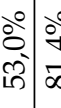 & 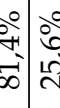 & 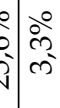 & \\
\hline $\begin{array}{l}\text { D } \\
\text { nి }\end{array}$ & $\begin{array}{l}\text { న్ } \\
\text { గn }\end{array}$ & જે & సิ & 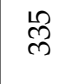 & $\infty$ & $\stackrel{m}{\wedge}$ & 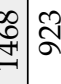 & $\begin{array}{l}\stackrel{\infty}{\llcorner} \\
\stackrel{(}{=}\end{array}$ & $\stackrel{\infty}{\infty}$ & $\begin{array}{l}0 \\
\text { 뭄 }\end{array}$ & เ્ర & 8 & 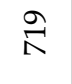 & $\begin{array}{ll}10 \\
8\end{array}$ & ஸి & 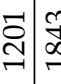 & \begin{tabular}{l|l}
$\infty$ \\
$\infty$ \\
$\infty$ \\
\end{tabular} & 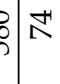 & \\
\hline 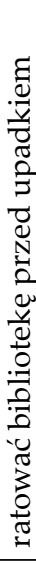 & 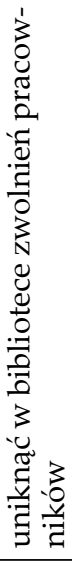 & 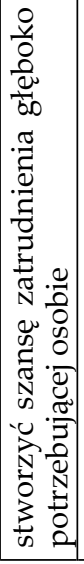 & 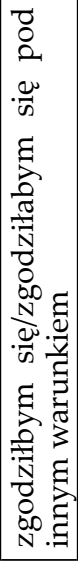 & 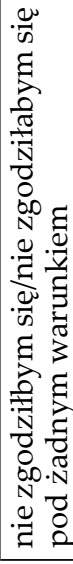 & 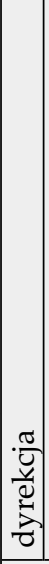 & 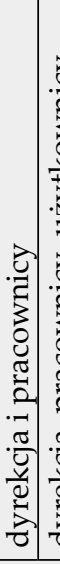 & 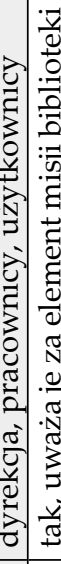 & 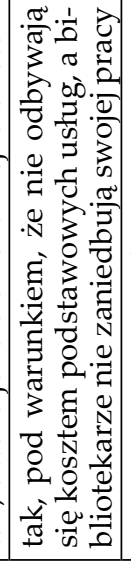 & 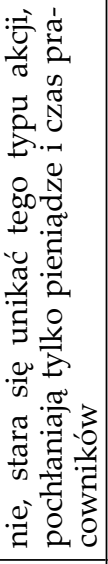 & 光 & $\stackrel{\mathscr{U}}{\Xi}$ & 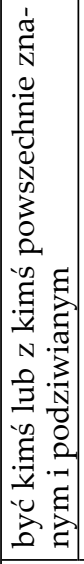 & 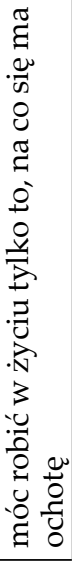 & 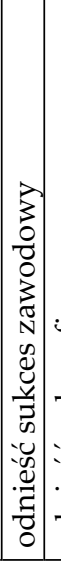 & 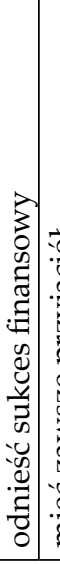 & 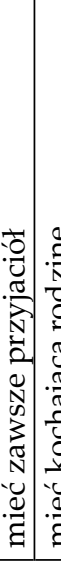 & 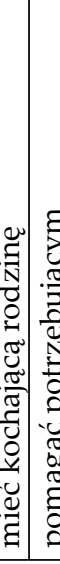 & 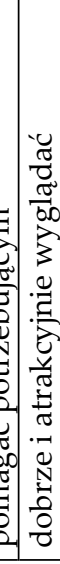 & \\
\hline & & 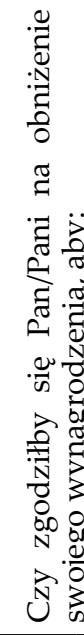 & & & (5) & 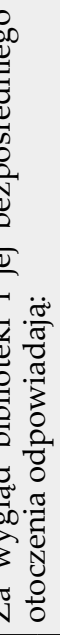 & & 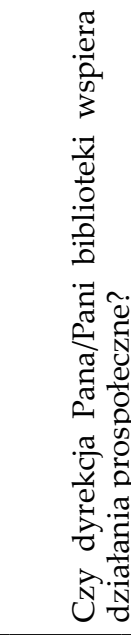 & & & 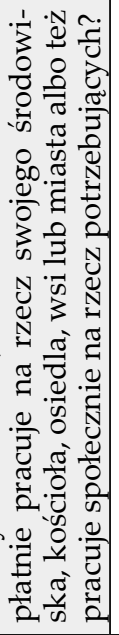 & & & 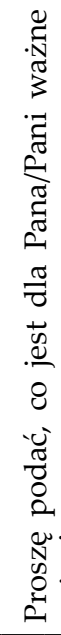 & 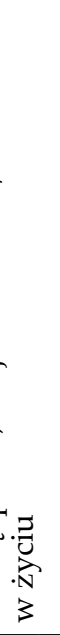 & & & & \\
\hline
\end{tabular}


Tabela 4

Statystyki różnic testu U Manna-Whitneya między dyrektorami i pracownikami liniowymi w zakresie częstości podejmowanych czynności związanych z aktywnością obywatelską

\begin{tabular}{|c|c|c|c|c|c|c|c|c|c|}
\hline & \multicolumn{6}{|c|}{ Stanowisko } & \multirow{2}{*}{\multicolumn{2}{|c|}{$\begin{array}{l}\text { Test U Manna } \\
\text { - Whitneya }\end{array}$}} \\
\hline & & \multicolumn{3}{|c|}{$\begin{array}{c}\text { Kadra kierownicza } \\
(\mathrm{n}=1171)\end{array}$} & \multicolumn{3}{|c|}{$\begin{array}{l}\text { Pracownik liniowy } \\
\qquad(\mathrm{n}=1671)\end{array}$} & & \\
\hline & & $\mathrm{M}$ & $\mathrm{ME}$ & SD & $\mathrm{M}$ & $\mathrm{ME}$ & SD & Z & $\mathrm{p}$ \\
\hline \multirow{6}{*}{ 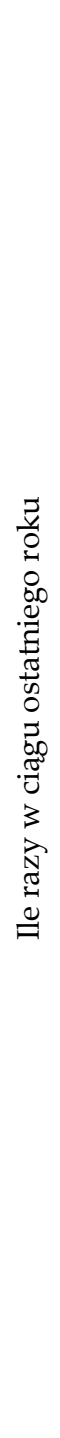 } & $\begin{array}{l}\text { brał/a Pan/Pani } \\
\text { udział w spotkaniu } \\
\text { publicznym z udzia- } \\
\text { łem mieszańców } \\
\text { dotyczący jakichś } \\
\text { praktycznych spraw } \\
\text { miejscowości, w któ- } \\
\text { rej pani mieszka? }\end{array}$ & 2,16 & 1,00 & 3,79 & 1,48 & 0,00 & 3,61 & $-11,2$ & $<0,01$ \\
\hline & $\begin{array}{l}\text { brał/a Pan/Pani } \\
\text { udział w jakimś ze- } \\
\text { braniu publicznym } \\
\text { niezwiązanym z wy- } \\
\text { konywaną pracą? }\end{array}$ & 3,05 & 2,00 & 5,89 & 3,04 & 1,00 & 9,38 & $-5,837$ & $<0,01$ \\
\hline & $\begin{array}{l}\text { podpisywał/a Pan/ } \\
\text { Pani jakąś petycję, } \\
\text { protest lub brał/a } \\
\text { udział w manifes- } \\
\text { tacji? }\end{array}$ & 2,04 & 1,00 & 8,29 & 2,66 & 1,00 & 9,19 & $-1,91$ & 0,056 \\
\hline & $\begin{array}{l}\text { informował/a Pan/ } \\
\text { Pani gazetę, radio, } \\
\text { telewizję, dyrekcję } \\
\text { szkoły, policję, wła- } \\
\text { dze o jakimś pro- } \\
\text { blemie (ustnie lub } \\
\text { pisemnie)? }\end{array}$ & 1,08 & 0,00 & 2,54 & 1,31 & 0,00 & 11,73 & $-5,779$ & $<0,01$ \\
\hline & $\begin{array}{l}\text { brał/a Pan/Pani } \\
\text { udział w zbiórce pie- } \\
\text { niędzy lub oferował/a } \\
\text { Pan/Pani pieniądze } \\
\text { na jakiś cel? }\end{array}$ & 4,16 & 2,50 & 6,10 & 4,52 & 2,00 & 7,98 & $-2,235$ & 0,025 \\
\hline & $\begin{array}{l}\text { brał/a Pan/Pani } \\
\text { udział w zbiórce da- } \\
\text { rów lub ofiarował/a } \\
\text { Pan/Pani jakieś rze- } \\
\text { czy w ramach akcji } \\
\text { charytatywnej? }\end{array}$ & 2,67 & 2,00 & 4,17 & 2,87 & 2,00 & 4,98 & $-0,989$ & 0,323 \\
\hline
\end{tabular}

M-średnia; ME-mediana; SD-odchylenie standardowe; Z-statystyka U Manna Whitneya; p-poziom istotności dla Z

Źródło: oprac. własne. 


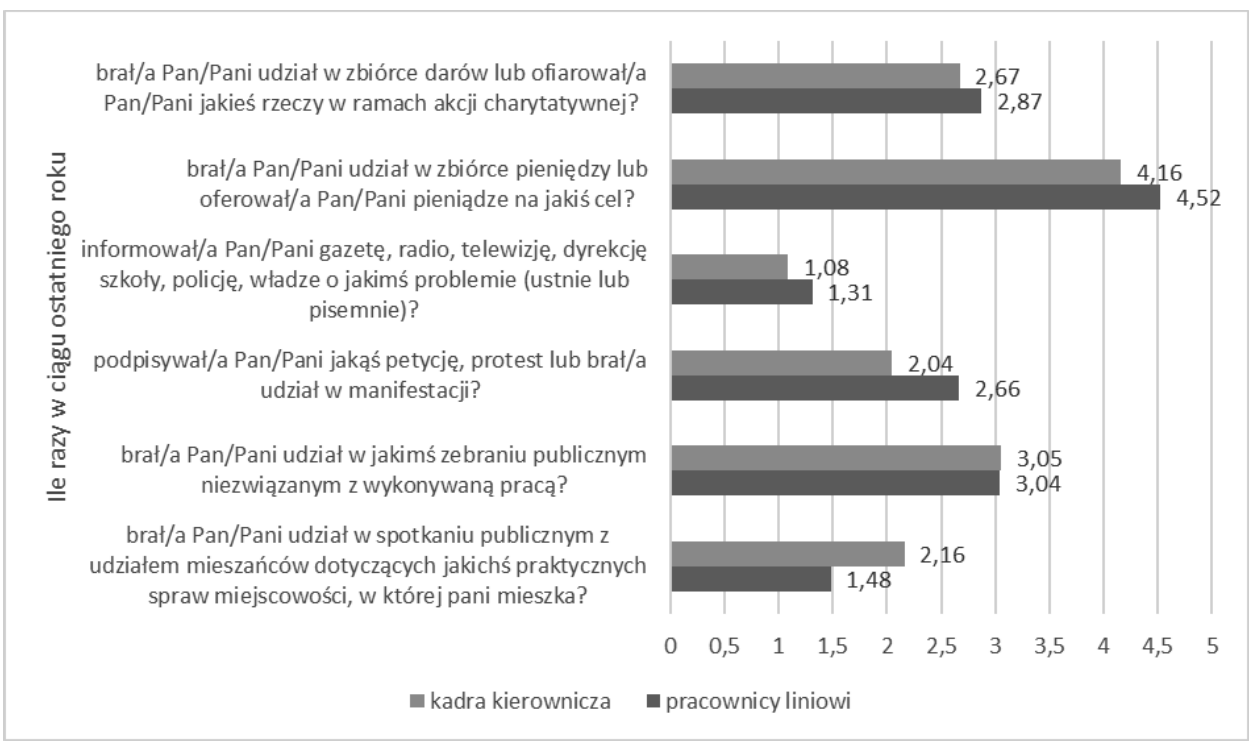

Rys. 2. Wykres wartości średnich częstości wykonywanych czynności w ciągu ostatniego roku w zależności od zajmowanego stanowiska

Źródło: oprac. własne.

Pracownicy liniowi częściej niż kadra kierownicza biorą udział w zbiórce darów, bądź ofiarowują jakieś rzeczy w ramach akcji charytatywnych, oraz biorą udział w zbiórkach pieniędzy lub ofiarowują je na jakiś cel. Również częściej informują gazetę, radio czy policję o jakimś problemie oraz podpisują petycje, protesty bądź biorą udział w manifestacjach. Kadra kierownicza bibliotek większą aktywnością wykazuje się jedynie $\mathrm{w}$ zakresie udziału $\mathrm{w}$ różnego rodzaju spotkaniach publicznych (niezwiązanych z pracą zawodową), np. z udziałem mieszańców dotyczących jakichś praktycznych spraw miejscowości, w której mieszka.

Kolejnym badanym aspektem była liczba znajomych, których posiadanie deklarowali respondenci. Jest to istotna informacja pokazująca aktywność jednostki w sieciach społecznych. Im większa aktywność, tym większa liczba znajomych, bardziej rozbudowane kontakty i sieci społeczne oraz większy dostęp do dóbr oraz wyższy poziom kapitału społecznego. Średnia liczba znajomych u dyrektorów i kierowników to 25,67 z odchyleniem standardowym 35,61. U pracowników liniowych to 22,46 z odchyleniem standardowym 31,89. Różnica w aktywności społecznej kadry kierowniczej i pracowników liniowych, przejawiająca się liczbą posiadanych znajomych jest istotna statystycznie i wynosi $\mathrm{p}<0,05$. Wynik ten jest zbieżny z ustaleniami innych autorów, którzy wskazywali, że kadra kierownicza powinna cechować się większą liczbą znajomych oraz wyższym poziomem kapitału społecznego (Growiec, s. 65-69). „Pracownicy umysłowi, wysoko kwalifikowani, na kierowniczych stanowiskach 
prowadzą zazwyczaj aktywne życie towarzyskie, budując ze znajomymi i przyjaciółmi bogatą sieć relacji uważaną za desygnat kapitału społecznego"' (Wojciechowska, 2019, s. 338).

\section{WNIOSKI}

Podsumowując: istotne statystycznie $(Z=-2,798 ; p=0,05)$ okazały się odpowiedzi wskazujące, że wyższy poziom indywidualnego kapitału społecznego obserwujemy u kadry kierowniczej $(67,26)$ niż u pracowników liniowych bibliotek (66,34). Różnica jest istotna, ale nie jest duża (Tab. 5).

Tabela 5

Statystyki poziomu indywidualnego kapitału społecznego według stanowiska

\begin{tabular}{|l|c|c|c|c|}
\hline \multicolumn{5}{|c|}{ Poziom indywidualnego kapitału społecznego } \\
\hline Stanowisko & Średnia & $\mathrm{N}$ & $\begin{array}{c}\text { Odchylenie } \\
\text { standardowe }\end{array}$ & $\begin{array}{c}\text { Test U Manna } \\
\text { Whitneya }\end{array}$ \\
\hline $\begin{array}{l}\text { kadra } \\
\text { kierownicza }\end{array}$ & 67,26 & 2846 & 10,822 & \multirow{2}{*}{$\mathrm{Z}=-2,798 ; \mathrm{p}=0,005$} \\
\hline $\begin{array}{l}\text { pracownik } \\
\text { liniowy }\end{array}$ & 66,34 & 3747 & 11,490 & \\
\hline Ogółem & 66,74 & 6593 & 11,215 & \\
\hline
\end{tabular}

Źródło: oprac. własne.

Również liczba znajomych jest wyższa wśród kadry kierowniczej i wynosi średnio 25,67. W przypadku aktywności społecznej i zaufania wyższym poziomem charakteryzuje się ponownie kadra kierownicza i dyrektorzy bibliotek. Z kolei aktywność obywatelska w niektórych aspektach jest wyższa u pracowników liniowych, w innych - u kadry kierowniczej. Kadra kierownicza jest ponadto nastawiona na osiagganie sukcesu zawodowego i rozwój własnej kariery, a także charakteryzuje się większą dbałością o dobro całej instytucji, w przeciwieństwie do pracowników liniowych, częściej kładących nacisk na dobro indywidualne.

Można zatem skomentować, że kadra kierownicza bibliotek reprezentuje postawy odnotowywane także wśród menedżerów innych typów instytucji i w większości spełnia warunki stawiane kadrze menedżerskiej w zakresie aktywizacji społecznej, posiada też cechy uznawane za istotne na stanowiskach kierowniczych. Niepokój budzi jednak niski poziom aktywności obywatelskiej dyrektorów i kierowników bibliotek, który na wielu polach jest niższy niż u pracowników liniowych. Może to utrudniać realizację niektórych zadań, ograniczać uczestnictwo w określonych projektach, powodować niezrozumienie bądź blokowanie aktywności podej- 
mowanych przez niższy personel i wreszcie ograniczać inspirację pochodzącą od przełożonych.

\section{BIBLIOGRAFIA}

Growiec, Katarzyna (2011). Kapitat społeczny. Geneza i społeczne konsekwencje. Warszawa: Academica.

Portes, Alejandro (1998). Social capital: its origins and applications in modern sociology. Annual Review of Sociology, vol. 24, pp. 1-24.

Raport o Kapitale Intelektualnym Polski (2008) [online]. Warszawa; [dostęp: 27.10. 2018]. Dostępny w WWW: <https://zds.kprm.gov.pl/przegladaj-raport-o-kapitale-intelektualnym>.

Styła, Rafał (2009). Kwestionariusz do Pomiaru Indywidualnego Kapitału Społecznego (KPIKS) - wstępna propozycja oparta na idei generatora zasobów Toma Snijdersa. Psychologia Społeczna, nr 1/2, s. 67-77.

Van der Gaag, Martin; Snijders, Tom A. B. (2004). Proposals for the measurement of individual social capital. In: Creation and returns of social capital: a new research program. Ed. by H. Flap, V. Beate. London: Routledge, pp. 199-218.

Van der Gaag, Martin; Snijders, Tom A. B. (2005). The Resource Generator: measurement of individual social capital with concrete items. Social Networks, nr 27, pp. 1-29.

Wojciechowska, Maja. (2019). Kształtowanie kapitału społecznego - ujęcie z perspektywy bibliotekoznawczej. Warszawa: Difin.

Wojciechowska, Maja; Kamińska, Joanna; Żołędowska-Król, Beata; Jaskowska, Bożena (2019). Leksykon zarządzania i marketingu w bibliotekoznawstwie. Warszawa: Wydaw. Naukowe i Edukacyjne SBP.

Artykuł w wersji poprawionej wptynąt do Redakcji 16 października 2020 r.

\section{MAJA WOJCIECHOWSKA}

Institute of Polish Language and Culture

Gdansk University

e-mail: maja.wojciechowska@gmail.com

\section{INDIVIDUAL SOCIAL CAPITAL AND SOCIAL ACTIVITY OF LIBRARY MANAGERS. REVIEWING THE RESULTS OF RESEARCH CONDUCTED IN TWENTY COUNTRIES}

KEYWORDS: Social capital. Library managers. Social activity. Social networks

ABSTRACT: Thesis/Objective - The author discusses the results of research on the level of individual social capital of librarians from 20 countries as well as their social activity - the researched issues have impact on the integration with local community and the 
development of various library services. The aim of this research was to discover if library managers participate in richer social networks, are more active socially and more willing to cooperate in comparison to other library staff - in short, if they display traits considered important for managerial positions. Research methods - The author received 6593 valid answers to an electronic survey and ran them through the statistical analysis. The following methods were used: one-way analysis of variance (ANOVA), chi-square test of independence and the Mann-Whitney U test. Results - The research confirmed an advanced social activity of library managers and higher levels of their individual social capital based on the responses to the Questionnaire for the Measurement of Individual Social Capital. 